\title{
NADAISMO Y MOVIMIENTO
}

José Fernando Gómez $\mathrm{H}$.

M. D. Geriátrica. Profesor Facultad de Fisioterapia. U. A. M.

\section{Anfora}

scapa al interés de este artículo buscar las fronteras d ? nadaismo por fuera de las fronteras colombianas, indagar sobre las bases que tuvo en André Bretón con sus manifiestos, en aquel «Enfant Terrible» de Arthur Rimbaud y sus persecuciones en el infierno. Porque es en la misma Colombia, con sus incomprensiones y sus contradicciones, siempre al orden del día desde tiempos inmemoriales, donde están los elementos que dieron posibilidades al nadaísmo, no sólo como expresión política, sino como la opción de atacar la norma: subvertirla, golpearla, desecharla, asesinarla.

Ya en el siglo pasado se habían hecho algunos intentos de infringir la norma: hablar de José Asunción Silva como el inspirador del proceso -cuantos del movimiento nadaísta lo leyeron?- en él es posible evidenciar algunos temas que luego retomarían los nadaístas para construir un cuerpo poético que originó toda serie de escándalos e indignados comentarios de la sociedad pacata de ese tiempo. Veamos un ejemplo de la obra, en la que tal vez Silva menos creyó, «Gotas Amargas», que se muestra como el augurio del movimiento:

«Del amor no sintió la intensa magia y consiguió... una buena blenorragia». 
En este siglo, con mayor frecuencia, aparecen otros poetas con las mismas tendencias: Luis Vidales, Luis Carlos López y el genialísimo León de Greiff. Y es en 1959 cuando el nadaísmo irrumpe con un agresivo manifiesto, aprovechando la oportunidad de un congreso de escribanos católicos en Medellín. manifiesto explosivo, humorístico, maledicente y lleno de provocación:

«Ustedes llevan dos mil años prometiendo el paraíso y la redención la justicia y la paz. No es suficiente su fracaso milenario? Permitan el acceso del conocimiento, del pensamiento científico, de la lógica histórica. Permitan que una política de la inmanencia restituya al hombre su posibilidades de salvación y de solidaridad humana que ustedes le negaron. Y no apesten más! En nombre del nadaísmo les impedimos defecarse una vez más en esta pobre alcantarilla que se llama Colombia».

Gonzalo Arango, El Profeta, lanza así su primera piedra contra la institución intocable de la sociedad colombiana, la iglesia, y crea el nadaísmo. Despúés el movimiento se propuso ir en contra de todo aquello que significara olor a tradición, alcanfor y conservadurismo. Fue en las cantinas, en los prostíbulos y en las calles donde nació, creció y se alimentó el movimiento poético más sui generis que haya tenido Colombia.

Pero por fuera de caracterizarlo como total anarquía social y moral. hay que mirar más adentro, donde es posible encontrar el verdadero sentido poético del movimiento, cuyas figuras más sobresalientes fueron: Jotamario Arbeláez, Elmo

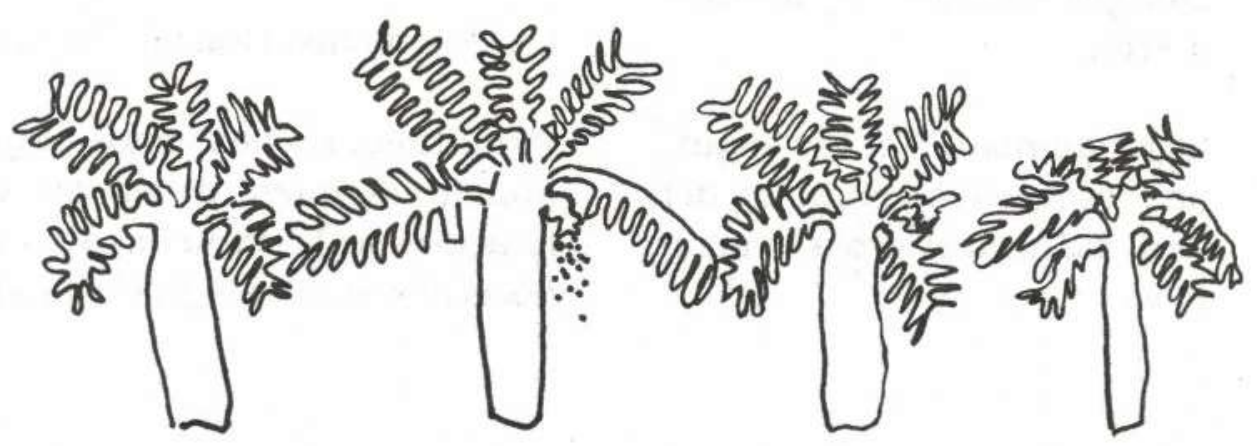

Universidad Autónoma 57 
Valencia, Jaime Jaramillo Escobar (X-504), Amilkar Osorio, Humberto Navarro, Eduardo Escobar, y el «verdadero santo del nadaísmo»: Dariolemos.

La vida de este último fue un infierno (o paraíso) nadaista: excomulgado por patear hostias, encarcelado por secuestrar su hijo a quien no le permitían ver, marihuanero irresoluto, ladrón compulsivo de amigos y conocidos que por «misericordia cristiana» lo hospedaban en casa, y quién terminó en un hospital psiquiátrico con ambas extremidades amputadas, debido a la gangrena que le originó un problema circulatorio de muchos años.

Estas son algunas recomendaciones nadaístas para nuestra cotidiana, predecible e inexorable vida:

«Me aventuro por las calles rabiosas de multitud y me hago perseguir por las miradas ojiverdes de la ley del más fuerte,

hago gimnasia por las esquinas, esquivo los embates del toro, me hago el loco a término fijo».
Nadaísta para siempre. Jotamario

«Podemos hacer siempre el paraíso alrededor de nosotros donde quiera que nos encontremos.

Para eso sólo se requiere estar desnudos»..

Apólogo del paraíso.

Jaime Jaramillo Escobar.

«el nadaísta es joven y resplancede de soledad...

no se suicida porque ama furiosamente fornicar

jugar billar-pool en las noches inagotables

brindar ron en honor a su existencia

estirarse en los prados bajo las lunas metálicas

no pensar

no cansarse

no morirse de felicidad ni de aburrimiento».

Los Nadaístas. Gonzalo Arango

Por último, no olvidemos palpar el húmero de nuestros amigos, como lo aconseja El Profeta, para reconocernos el día del juicio final. 